\title{
Kemampuan Ibu Hamil Mengenali Tanda Bahaya Kehamilan, Persalinan dan Nifas di kelas Ibu Hamil Wilayah Kerja Puskesmas Putri Ayu Kota Jambi
}

\author{
Herinawati $^{1}$, Lia Artika Sari ${ }^{2}$, Atika Fadhilah Danaz Nasution ${ }^{3}$ \\ ${ }^{1-3}$ Poltekkes Kemenkes Jambi \\ Email: herinawati_burhanuddin@yahoo.com
}

Submitted : 20/02/2020

Accepted: 04/03/2020

Published: $7 / 09 / 2020$

\begin{abstract}
Pregnant mothers class to learn about health for pregnant women in the form of face-to-face in groups who want to improve the knowledge, attitudes, and skills of mothers and families regarding assessment, care, childbirth, childbirth care, illness, or situations during pregnancy-childbirth and childbirth, care newborn babies use the Mother and Child Health book (MCH) as the main ingredient. High-risk pregnant women in Puskesmas putri ayu experienced an increase in 2018 (January-December) increased by 146 high-risk pregnant women and in 2019 (January august) there were 152 high-risk pregnant women. The purpose of this study was to study the effect of education on information and communication on the ability of pregnant women to face the challenges of pregnancy, childbirth and childbirth in pregnant mothers working area of the Putri Ayu Public Health Center in 2019. The method of this study used a quasi-study with one group pretest-postet design. The sampling technique in this study was a total sampling of 50 respondents. analysis using the Wilcoxon test. Research results obtained by pregnant women $p$ value of .000, childbirth with a $p$ value of .000 and puerperium $p$ value of .0009 means related to education education about health and safety for pregnant women who associate the problem of childbirth danger in the class of pregnant women at the working area of Putri Ayu Health Center Jambi in 2019. It is expected that midwives' special health centers will improve their communication skills, through health counseling, this can be used as a health workforce program in providing health education.
\end{abstract}

Keywords: childbirth, effect of education, pregnant mothers

\begin{abstract}
Abstrak
Kelas ibu hamil adalah sarana untuk belajar tentang kesehatan bagi ibu hamil dalam bentuk tatap muka dalam kelompok yang bertujuan untuk meningkatkan pengetahuan, sikap, dan keterampilan $i b u$ dan keluarga mengenai kehamilan, perawatan kehamilan, persalinan, perawatan nifas penyakit atau komplikasi saat hamil-bersalin dan nifas, perawatan bayi baru lahir menggunakan buku Kesehatan Ibu dan Anak (KIA) sebagai materi utama. Ibu hamil dengan resiko tinggi di Puskesmas putri ayu mengalami peningkatan pada Tahun 2018 (Januari-Desember) berjumlah 146 ibu hamil resiko tinggi dan tahun 2019 (januari agustus) berkumlah 152 ibu hamil resiko tinggi. Tujuan penelitian ini untuk mengetahui pengaruh edukasi halinfas terhadap kemampuan ibu hamil mengenali tanda bahaya kehamilan, persalinan dan nifas dikelas ibu hamil wilayah kerja Puskesmas Putri Ayu Kota Jambi Tahun 2019. Metode penelitian ini menggunakan quasi eksperimen dengan the one grup pretest-postets design. Teknik pengambilan sampel dalam penelitian ini adalah total sampling berjumlah 50 responden. analisis dengan menggunakan uji Wilcoxon.Hasil penelitian didapat kemampuan ibu hamil $p$ value sebesar ,000, persalinan dengan $p$ value sebesar,000 dan nifas $p$ value sebesar,000 berati terdapat pengaruh edukasi halinfas terhadap kemampuan ibu hamil mengenali tanda bahaya nifas dikelas ibu hamil wilayah kerja Puskesmas Putri Ayu Kota Jambi Tahun 2019. Diharapkan kepada pihak puskesmas khususnya bidan untuk lebih meningkatkan kemampuan berkomunikasi, melalui penyuluhan kesehatan, hal ini dapat dijadikan sebagai program tenaga kesehatan dalam memberikan pendidikan kesehatan.
\end{abstract}

Kata kunci:ibu hamil, pendidikan, persalinan 


\section{PENDAHULUAN}

Program pembangunan kesehatan di Indonesia, dewasa ini masih di prioritaskan pada upaya peningkatan derajat kesehatan, utamanya pada kelompok paling rentan kesehatan, yaitu ibu hamil, ibu bersalin dan ibu nifas serta bayi pada masa perinatal, hal ini ditandai dengan masih tingginya angka kematian ibu (AKI) dan angka kematian bayi (AKB). Berdasarkan Survey Demografi dan Kesehatan Indonesia (SDKI) 2018, angka kematian ibu (AKI) di Indonesia masih 305/100.000 kelahiran hidup. Hal ini dapat diasumsikan bahwa setiap jam terdapat sekitar 2 (dua) orang ibu bersalin yang meninggal dunia karena berbagai sebab. Demikian pula dengan angka kematian bayi (AKB), khususnya angka kematian bayi baru lahir (neonatal) masih berada di kisaran 20 per 1000 kelahiran hidup. Tingginya AKI dan AKB antara lain disebabkan karena ketidakberdayaan seorang ibu dalam memutuskan untuk mendapatkan pertolongan medis apabila terjadi permasalahan pada kehamilan dan bayinya. Hal ini antara lain disebabkan oleh rendahnya pengetahuan ibu dalam perawatan kesehatan ibu serta pengenalan tanda-tanda bahaya obstetric dan neonatal, sehingga akan menghambat suatu keputusan yang harus diambil.

Salah satu upaya untuk dapat memberikan pengetahuan yang cukup kepada ibu hamil dan keluarga adalah melalui kelas ibu hamil. Kelas ibu hamil adalah sarana untuk belajar tentang kesehatan bagi ibu hamil dalam bentuk tatap muka dalam kelompok yang bertujuan untuk meningkatkan pengetahuan, sikap, dan keterampilan ibu dan keluarga mengenai kehamilan, perawatan kehamilan, persalinan, perawatan nifas penyakit atau komplikasi saat hamil-bersalin dan nifas, perawatan bayi baru lahir menggunakan buku
Kesehatan Ibu dan Anak (KIA) sebagai materi utama (Husodo).

Keikutsertaan ibu hamil dan keluarga pada kelas ibu hamil diharapkan dapat meningkatkan pengetahuan dan perubahan perilaku ibu hamil dan keluarga. Dengan meningkatnya pengetahuan dan perubahan perilaku ini diharapkan kesadaran terhadap pentingnya perawatan kesehatan selama kehamilan dan pengenalan tanda komplikasi menjadi meningkat (Sudaya). Kelas ibu hamil merupakan kegiatan pemberdayaan masyarakat melalui sarana belajar kelompok tentang kesehatan ibu hamil dengan memanfaatkan buku KIA).

Penelitian yang dilakukan Hastuti, dkk (2011) di wilayah kabupaten Magetan, Jawa Timur menunjukkan bahwa kelas ibu hamil efektif untuk meningkatkan pengetahuan, sikap, keterampilan, dan kunjungan antenatal care (ANC) dan penelitian lain yang dilakukan oleh Yanti (2013) yang mengevaluasi program kelas ibu hamil di Kabupaten Batang menunjukan bahwa pemberian intervensi berupa kelas ibu hamil mampu meningkatkan pengetahuan dan sikap yang positif tentang kehamilan dan persalinan pada ibu hamil.

Ibu hamil dengan resiko tinggi di Puskesmas putri ayu mengalami peningkatan pada Tahun 2018 (JanuariDesember) berjumlah $146 \mathrm{ibu}$ hamil resiko tinggi dan tahun 2019 (januari agustus) berkumlah 152 ibu hamil resiko tinggi. Berdasarkan data diatas peneliti tertarik melakukan penelitian dengan judul Edukasi Halinfas Terhadap Kemampuan Ibu Hamil Mengenali Tanda Bahaya Kehamilan, Persalinan Dan Nifas Dikelas Ibu Hamil Wilayah Kerja Puskesmas Putri Ayu Kota Jambi Tahun 2019.

\section{METODE PENELITIAN}

Peneliti memberikan pretest pada responden untuk mengetahui sejauh mana pengetahuan yang dimiliki responden mengenai tanda bahaya pada masa 
kehamilan, persalinan dan nifas, setelah diberikan pretest, peneliti melakukan eksperimen dengan memberikan edukasi halinfas berupa pendidikan tentang tandatanda bahaya selama masa kehamilan, persalinan dan nifas. Tindakan akhir yang dilakukan peneliti memberikan posttest dengan tujuan untuk mendapatkan perbandingan data dari pretest ke tes posttest.Penelitian ini dilakukan di wilayah kerja di Puskesmas Putri Ayu Kota Jambi berlokasi di kelurahan Murni, kelurahan solok sipin, kelurahan legok, kelurahan Sungai Putri dan kelurahan selamat. Penelitian ini dilaksanakan pada bulan April-November 2019 dan pengambilan data dilakukan pada bulan September dan Oktober 2019.Populasi dalam penelitian ini adalah seluruh ibu hamil trimester I, II, dan III yang mengikuti kegiatan kelas ibu hamil berjumlah 50 ibu hamil. Teknik pengambilan sampel dalam penelitian ini adalah total sampling. Total sampling adalah teknik pengambilan sampel dimana jumlah sampel sama dengan populasi (sugiono, 2007). Analisa data dilakukan dengan menggunakan uji Wilcoxon.

\section{HASIL DAN PEMBAHASAN}

Hasil

Tabel 1. Kemampuan ibu hamil mengenali tanda bahaya kehamilan sebelum dan sesudah edukasi

\begin{tabular}{lllll}
\hline & \multicolumn{2}{c}{$\mathrm{N}$} & \multicolumn{2}{c}{$\mathrm{N}$} \\
\cline { 2 - 5 } & $\mathrm{f}$ & $\%$ & $\mathrm{f}$ & $\%$ \\
\cline { 2 - 5 } & \multicolumn{2}{c}{ Sebelum } & \multicolumn{2}{c}{ Sesudah } \\
& edukasi & \multicolumn{2}{c}{ edukasi } \\
\hline Tidak mampu & 33 & 66 & 9 & 18 \\
Mampu & 17 & 34 & 4 & 82 \\
& & & 1 & \\
\hline
\end{tabular}

Berdasarkan tabel 1 sebanyak 33 orang $(66 \%)$ ibu tidak mampu mengenali tanda bahaya kehamilan dan 17 orang (34\%) mampu mengenali tanda bahaya kehamilan, setelah dilakukan edukasi halinfas jumlah ibu yang mampu mengenali tanda bahaya kehamilan naik menjadi 41 orang $(82 \%)$.

Tabel 2. Kemampuan ibu hamil mengenali tanda bahaya persalinan sebelum dan sesudah edukasi

\begin{tabular}{llccc}
\hline & \multicolumn{2}{c}{$\mathrm{N}$} & \multicolumn{2}{c}{$\mathrm{N}$} \\
& $\mathrm{F}$ & \multicolumn{1}{c}{$\mathrm{f}$} & $\%$ \\
\hline & Sebelum & \multicolumn{2}{c}{ Sesudah } \\
Tidak mampu & edukasi & \multicolumn{2}{c}{ edukasi } \\
Mampu & 37 & 74 & 4 & 8 \\
\hline
\end{tabular}

Berdasarkan tabel 2 sebanyak 37 orang (74\%) ibu tidak mampu mengenali tanda bahaya persalinan dan 13 orang (26\%) mampu mengenali tanda bahaya persalinan, setelah dilakukan edukasi halinfas jumlah ibu yang mampu mengenali tanda bahaya persalinan naik menjadi 46 orang (92\%) mampu mengenali tanda bahaya persalinan.

Tabel 3. Kemampuan ibu hamil mengenali tanda bahaya nifas sebelum dan sesudah edukasi

\begin{tabular}{lcccr}
\hline & \multicolumn{2}{c}{$\mathrm{N}$} & \multicolumn{2}{c}{$\mathrm{N}$} \\
& $\mathrm{f}$ & $\%$ & $\mathrm{f}$ & $\%$ \\
\hline & Sebelum & \multicolumn{2}{c}{ Sesudah } \\
Tidak mampu & 37 & 7 & 7 & 1 \\
& & 4 & & 4 \\
Mampu & 13 & 2 & 43 & 8 \\
& & 6 & & 6 \\
\hline
\end{tabular}

Berdasarkan tabel 3 sebanyak 37 orang (74\%) ibu tidak mampu mengenali tanda bahaya nifas dan 13 orang (26\%) mampu mengenali tanda bahaya nifas, setelah dilakukan edukasi halinfas jumlah ibu yang mampu mengenali tanda bahaya nifas naik menjadi 43 orang $(86 \%)$ mampu mengenali tanda bahaya nifas.

Tabel 4. Pengaruh edukasi terhadap kemampuan ibu hamil mengenali tanda bahaya kehamilan 


\begin{tabular}{cc}
\hline & $\begin{array}{l}\text { kemampuan sebelum } \\
\text { edukasi kehamilan } \\
\text { kemampuan setelah } \\
\text { edukasi kehamilan }\end{array}$ \\
\hline Z & $-4,899^{\mathrm{a}}$ \\
Asymp. Sig. &, 000 \\
(2-tailed) & \\
\hline
\end{tabular}

Berdasarkan tabel 4 nilai $\mathrm{Z}$ yang didapat sebesar $-4,899$ dengan $p$ value sebesar ,000 berarti terdapat pengaruh edukasi edukasi halinfas terhadap kemampuan ibu hamil mengenali tanda bahaya kehamilan dikelas ibu hamil wilayah kerja Puskesmas Putri Ayu Kota Jambi Tahun 2019.

Tabel 5. Pengaruh edukasi terhadap kemampuan ibu hamil mengenali tanda bahaya persalinan

\begin{tabular}{ll}
\hline & kemampuan \\
& sebelum edukasi \\
& persalinan \\
& kemampuan \\
& setelah edukasi \\
& persalinan \\
\hline $\mathrm{Z}$ & $-5,477^{\mathrm{a}}$ \\
Asymp. Sig. (2-tailed) &, 000 \\
\hline
\end{tabular}

Berdasarkan tabel 5 nilai $\mathrm{Z}$ yang didapat sebesar $-5,477$ dengan $p$ value sebesar ,000 berarti terdapat pengaruh edukasi halinfas terhadap kemampuan ibu hamil mengenali tanda bahaya persalinan dikelas ibu hamil wilayah kerja Puskesmas Putri Ayu Kota Jambi Tahun 2019

Tabel 6. Pengaruh edukasi terhadap Kemampuan ibu hamil mengenali tanda bahaya nifas

\begin{tabular}{ll}
\hline & $\begin{array}{l}\text { kemampuan sebelum } \\
\text { edukasi nifas } \\
\text { kemampuan setelah } \\
\text { edukasi nifas }\end{array}$ \\
\hline $\mathrm{Z}$ & $-5,745^{\mathrm{a}}$ \\
$\begin{array}{l}\text { Asymp. Sig. (2- } \\
\text { tailed) }\end{array}$ &, 000 \\
\hline
\end{tabular}

Berdasarkan tabel 6 nilai $\mathrm{Z}$ yang didapat sebesar $-5,745$ dengan $p$ value sebesar ,000 berarti terdapat pengaruh edukasi halinfas terhadap kemampuan ibu hamil mengenali tanda bahaya nifas dikelas ibu hamil wilayah kerja Puskesmas Putri Ayu Kota Jambi Tahun 2019

\section{Pembahasan}

Berdasarkan hasil penelitian diatas di dapatkan kemampuan ibu hamil mengenali tanda bahaya kehamilan, persalinan dan nifas dikelas ibu hamil wilayah kerja Puskesmas Putri Ayu Kota Jambi sebagian besar memiliki kemampuan kurang sebelum dilakukan edukasi halinfas. dan kemampuan ibu meningkat setelah diberikan edukasi halinfas.

Menurut Saifuddin (2002), bahwa jenjang pendidikan sangat mempengaruhi terhadap hal untuk memperoleh informasi, dan hak menolak atau menerima penjelasan yang diberikan. Kemudian semakin baik pendidikan orangtua maka orang tua akan semakin mudah menerima informasi dari luar mengenai tanda-tanda bahaya kehamilan, persalinan dan nifas. Pada umumnya makin tinggi pendidikan seseorang makin mudah menerima atau menyerap informasi yang didapat. Pendidikan dapat mempengaruhi pengetahuan seseorang, tingkat pendidikan dapat berkaitan dengan kemampuan menyerap dan menerima informasi kesehatan, demikian juga orang tua atau ibu. Semakin tinggi pendidikan seseorang biasanya mempunyai pengetahuan dan wawasan yang lebih luas sehingga akan lebih mudah menerima informasi kesehatan.

Pendapat diatas sesuai dengan hasil penelitian ini dimana sebagian besar responden memiliki tingkat pendidikan SMU hal ini yang mempengaruhi seseorang untuk memperoleh informasi yang baik, menerima penjelasan yang diberikan sehingga responden memiliki berkemampuan baik dalam mengenali 
tanda-tanda bahaya pada kehamilan, persalinan dan nifas.

Peneliti berpendapat, tingkat pendidikan turut menentukan mudah tidaknya seseorang menyerap dan memahami suatu pengetahuan mengenali tanda bahaya pada kehamilan, persalinan dan nifas yang benar sesuai dengan yang mereka peroleh. Dari uraian ini dapat disimpulkan bahwa semakin tinggi pendidikan seseorang maka semakin baik pula pengetahuannya sehingga makin mudah seseorang tersebut menerima informasi. Pendidikan mempengaruhi proses belajar, makin tinggi pendidikan seseorang, makin mudah orang tersebut menerima informasi.

$$
\text { Hasil penelitian lainnya }
$$
menyebutkan bahwa terdapat hubungan antara pengetahuan dan sikap dengan penggunaan buku KIA, 78 ibu hamil yang memiliki buku KIA memiliki pengetahuan baik. Begitu pula penelitian di Bojonegoro diketahui bahwa proporsi responden yang baik dalam memanfaatkan buku KIA $(56,25 \%)$ lebih besar daripada proporsi responden yang kurang dalam memanfaatkan buku KIA.

Hasil analisis bivariat menunjukkan bahwa ada pengaruh edukasi halinfas terhadap kemampuan ibu hamil mengenali tanda bahaya kehamilan, persalinan dan nifas dikelas ibu hamil wilayah kerja Puskesmas Putri Ayu Kota Jambi. Ibu memiliki kemampuan baik tentang tanda bahaya kehamilan, persalinan dan nifas karena keikutsertaan ibu dalam kelas ibu hamil yang mana ibu memperoleh ilmu pengetahuan tentang tanda bahaya kehamilan dengan membaca buku KIA dan mendapatkan penjelasan serta diskusi tentang materi tersebut saat mengikuti kelas ibu.

Hasil penelitian yang dilakukan di kota bogor, frekuensi keikutsertaan dalam kelas ibu hamil ini berperan penting peningkatan kemampuan ibu tentang tanda-tanda bahaya kehamilan dan komplikasi kehamilan. Berdasarkan hasil penelitian dan pendapatpendapat tersebut di atas maka dapat dijelaskan bahwa pada saat ibu hamil mengikuti kelas ibu hamil yang diadakan oleh Puskesmas ibu hamil akan mendapatkan informasi yang jelas mengenai seputar kehamilan, persalinan, nifas, dan mengenai tanda bahaya kehamilan. Hasil penelitian inipun sesuaI dengan pernyataan bahwa tujuan pendidikan kesehatan adalah informasi yang diberikan kepada ibu hamil memberikan banyak manfaat dimana tanda bahaya kehamilan, persalinan dan nifas dapat diketahuinya, sehingga ibu hamil dapat mewaspadai kalau mengalami salah satu dari tanda bahaya kehamilan, persalinan dan nifas tersebut dan dapat segera mencari pertolongan ke bidan ataupun tenaga kesehatan lainnya yang pada akhirnya dapat mengurangi resiko komplikasi dari tanda bahaya kehamilan tersebut.

Hasil penelitian ini menguatkan bahwa keikutsertaan ibu hamil dalam kelas ibu hamil berperan dalam meningkatkan kemampuan ibu mengenal tanda bahaya kehamilan, persalinan dan nifas. . Peran kelas ibu hamil dapat meningkatkan pengetahuan tentang tanda-tanda bahaya kehamilan, maka setiap kelas program kelas ibu hamil yang berjalan akan berkontribusi terhadap upaya penurunan AKI dan AKBA. Pengelolaan program kelas ibu hamil yang baik akan menghasilkan lulusan Kelas Ibu Hamil baik ibu hamil maupun keluarganya (suami atau keluarga lain) yang siap menghadapi kondisi kegawatdaruratan sehingga bisa segera teratasi dan mendapat pelayanan kesehatan yang memadai.

\section{SIMPULAN}

Sebagian kecil ibu hamil kurang mampu mengenali tanda bahaya kehamilan, persalinan dan nifas dikelas ibu hamil wilayah kerja Puskesmas Putri Ayu Kota 
Jambi sebelum di berikan edukasi halinfas.Sebagian besar ibu hamil mampu mengenali tanda bahaya kehamilan, persalinan dan nifas dikelas ibu hamil wilayah kerja Puskesmas Putri Ayu Kota Jambi setelah di berikan edukasi halinfas. Ada pengaruh edukasi halinfas terhadap kemampuan ibu hamil mengenali tanda bahaya kehamilan, persalinan dan nifas dikelas ibu hamil wilayah kerja Puskesmas Putri Ayu Kota Jambi Tahun 2019 Diharapkan kepada pihak puskesmas khususnyas bidan untuk lebih meningkatkan kemampuan berkomunikasi, melalui penyuluhan kesehatan, hal ini dapat dijadikan sebagai program tenaga kesehatan dalam memberikan pendidikan kesehatan.

\section{DAFTAR PUSTAKA}

BPS. 2012. Survey Dasar Kesehatan Indonesia. Jakarta: BPS dan BKKBN

Carina S. Brixval*, Solveig F. Axelsen, Lau C. Thygesen, Pernille Due, Vibeke Koushede , 2016 , Antenatal education in small classes may increase childbirth selfefficacy: Results from a Danish randomised trial, Sexual \& Reproductive

Harahap. 2016. Pengaruh Kelas Ibu Hamil Terhadap Pengetahuan dan Sikap Ibu Tentang Perawatan Selama Kehamilan, dan Nifas di Wilayah Kerja Puskesmas Karang Rejo Kabupaten Langkat. Tesis. Program Studi S2 Ilmu Kesehatan Masyarakat Fakultas Kesehatan Masyarakat Universitas Sumatera Utara Medan

Hastuti, P.S., Nugroho, H.S., dan Usnawati, N., 2011. Efektifitas Pelatihan Kelas Ibu Hamil untuk Meningkatkan Pengetahuan, Sikap, Keterampilan dan Kunjungan Antenatal Care. Jurnal Penelitian Kesehatan Suara Forikes, II (2)

Historyati Dyah. Hubungan Pengetahuan dan Sikap Ibu Hamil Tentang Kelas Ibu Hamil dengan Partisipasi dalam
Kelas Ibu Hamil Di wilayah Kerja Puskesmas Tembelang. UNS Solo; 2003.

Kawakatsu, Y., Sugishita, T., Oruenjo, K., Wakhule, S., Kibosia, K., \& Were, E. (2014). Determinants Of Health Facility Utilization For Childbirth In Rural Western Kenya : CrossSectional Study. BMC Pregnancy and Childbirth

Kemenkes . 2014. Pedoman Pelaksanaan Kelas Ibu Hamil. Jakarta: Kemenkes RI

Kemenkes. 2015. Modul Pelatihan Bagi Pelatih Fasilitator Kelas Ibu (Kelas Ibu Hamil dan Kelas Ibu Balita). Jakart: Kemenkes RI

Kemenkes. 2016. Buku Kesehatan Ibu dan Anak. Jakarta: Kemenkes RI

Kusindinjah. Hubungan kepemilikan buku KIA dengan pengetahuan,sikap dan praktik perawatan kehamilan di wilayah kerja Puskesmas Rangkah Surabaya. Embrio,Jurnal Kebidanan. 2012;I(1):42-

Lestari, T. 2015. Kumpulan Teori Untuk Kajian Pustaka Penelitian Kesehatan. Yogyakarta: Nuha Medika

Linarsih. 2012. Pengaruh Kelas Ibu Hamil Terhadap Peningkatan Pengetahuan dan Keterampilan Ibu Hamil Mengenai Kesehatan Ibu dan Anak Di Wilayah Puskesmas Sempor II Kabupaten Kebumen. Skripsi. Fakultas Kesehatan Masyarakat Program Sarjana Kesehatan Masyarakat Depok

Mandriwati. 2008. Penuntun Belajar Asuhan Kebidanan Ibu Hamil. Jakarta: EGC

Pangesti, W.D., dan Kusuma, I.R., 2013. Pengaruh Kelas Ibu Hamil terhadap Perilaku Ibu dalam Asuhan Antenatal di Puskesmas Patikraja Banyumas, Purwokerto : Artikel Penelitian Fikes Universitas Muhammadiyah 
Rahma. 2017. Analisis Pemanfaatan Pelayanan Persalinan Pada Fasilitas Kesehatan Berdasarkan Kelas Ibu Hamil Di Puskesmas Hila Kabupaten Maluku Tengah Tahun 2017. Tesis. Program Pascasarjana Universitas Hasanuddin Makassar

Rante,S. 2018. Hubungan Keikutsertaan Ibu Primigravida Dalam Kelas Ibu Hamil Dengan Kesiapan Menghadapi Persalinan Di Wilayah Kerja Puskesmas Toari Kecamatan Toari Kabupaten Kolaka Tahun 2018. Skripsi. Politeknik Kesehatan Kendari Prodi D-IV Kebidanan Kendari

Redshaw M \& Henderson J. (2013).Fathers Engagement In Pregnancy And Child- Birth: Evidence From A National Survey. BMC Pregnancy and Child- birth, 13(70), 1-15 Penelitian Weitzman A, (2016) di Peru

Stephen. P. Robbins, Perilaku Organisasi, Edisi Bahasa
Indonesia, Pearson Educations. Inc, 2006 hasil penelitian Fatimah, et al (2012)

Wawan, Dewi. 2011. Teori Dan Pengukuran Pengetahuan, Sikap, Dan Perilaku Manusia. Yogyakarta: Nuha Medika

WHO. 2015. Trends in Maternal Mortality: 1990 to 2015, Unicef, Unfpa, World Bank Group and The United Nations Population Division). Ganeva, Switzerland Kemenkes RI. 2013. Hasil Riskesdas Tahun 2012. Jakarta

Widagdo L, Husodo BT. Pemanfaatan Buku Kia Oleh Kader Posyandu: Studi Pada Kader Posyandu Di Wilayah Kerja Puskesmas Kedungadem Kabupaten Bojonegoro

Yanti, dkk .2013. Evaluasi Program Kelas Ibu Hamil Di Puskesmas Wilayah Kabupaten Batang Tahun 2012. Tesis.Universitas Diponegoro 